\title{
Biodeversity of Insect Affect on Rice Field and their Management in the Fingeshwar Region
}

\author{
Kavita Gabel $^{1}$, Manoj Gabhel ${ }^{2}$ \\ ${ }^{1}$ M. Phil. Scholar, Dr. C.V. Raman University Bilaspur (C.G) \\ ${ }^{2}$ Assistant Professor, Dr. C.V. Raman University Bilaspur (C.G)
}

\begin{abstract}
This study has helped to identify insect life cycle to check economic loss to farmer. It also help into choosing of insecticides in various stage of insect and help to economic enhancements of crop and market value of product. To get economic production it is essential to combine all suitable techniques and methods of pest suppression in as compatible a manner as possible to maintain pest populations at levels below those causing economic injury
\end{abstract}

Keywords: Insect biodiversity, major pests of rice, diversity of rice pests

\section{Introduction}

India is a predominantly agriculture based economy country. The productivity of crop increased in India due to increase in irrigated area; introduction of HYV and improved management practices. But, it is not true in Eastern India as a whole and Chhattisgarh in particular due to diverse crop growing environment, land situations, physiographic and socio-economic conditions of the farmers. Crop production occurs in a dynamic environment. It has been experienced that cropping system of a region is the mirror of socioeconomic condition of farmers, irrigation network, marketing and processing infrastructure of the area and ultimately agricultural scenario of the state. Farmers with their vast experience and practicability have established the best suited cropping systems in different region that are economically viable and environmentally sustainable. The information on crop cover in growing period with the use of internal and external resources can be used to intensify the cropping system or to adjust additional crop to make cropping system more profitable.

The rice plant is subject to attack by more than 100 species of insects; 20 of them can cause economic damage. Together they infest all parts of the plant at all growth stages, and a few transmit viral diseases. The major insect pests that cause significant yield losses are leafhoppers and planthoppers, which cause direct damage as well as transmit viruses; stem borers; and a group of defoliator species. As in many other agroecosystems, the rice agroecosystem has a few primary pests that may actually limit production under certain conditions. In addition to the primary pests are numerous species that cause periodic losses, and a few species that may occur in such low numbers that no damage occurs. Since the introduction of highyielding varieties, distinct changes have occurred in the insect pest complex of rice in Asia. Several species, which once were considered minor pests. Examples are the brown planthopper, white backed planthopper, green leafhopper, and leaf folders. Until the 1960s, the stem borers were considered the most serious pests of rice throughout the tropics.

In agro-ecosystems, biodiversity has a positive correlation with agricultural production within a certain range: as the biodiversity increases, the agricultural production also increases. On the contrary, when biodiversity decreases, the agricultural production 2 also will decrease. One of the main reasons is that it can effectively control the number of insect pests. According to the statistics by Risch, the number of plant eaters has reduced by $53 \%$ and the number of plant eaters has increased by $18 \%$ by decreasing the biodiversity of agro-ecosystems. As for plants, the diversification of complex environment can provide a series of alternative of prey and micro habitats and can form a relatively stable community, which can effectively control the pests. Despite the negative effect of weeds on crop production, it is important to maintain weed diversity in farmland, as weeds can provide diverse ecological services in relation to maintaining the stability and sustainability of agroecosystems. In fact, arable weeds constitute the base of the food chain for herbivores and their natural enemies. Additionally, arable weeds also support various species of beneficial insects, especially crop pollinators. Meanwhile, high weed diversity is favourable in maintaining and regulating the microbial diversity of the soil and reducing the effects of harmful weeds.

Modern intensive agricultural practices, especially pesticide and fertilizer use and excessive, inadequately coordinated development and landscape transformation, have not only polluted the water and soil environments, but have also destroyed the biological refuge and habitat provided by paddy fields. It is well known that rice paddy biodiversity provides the foundation to maintain stable paddy field ecosystems and contributes substantially to the ecosystem services that paddy fields provide, thus creating economic value for society.

Rice is one of the major staple food crops of Chhattisgarh and grown at different agro-climatic zones, occupying an area of 14.5 lakh hectare. Though more than 28 insect species have been reported to attack rice in Chhattisgarh, the distribution and intensity of insect pest attackvaries from zone to zone. Yellow stem borer (Scirpophaga incertulas Walker) and the leaf roller [(Cnaphalocrocis medinalis (Guenee)] are observed in all the rice growing zones. Brown planthopper (Nilaparvata lugens Stal.) reported from Raipur 


\section{International Journal of Science and Research (IJSR) \\ ISSN (Online): 2319-7064}

Index Copernicus Value (2015): 78.96 Impact Factor (2015): 6.391

district of Chhattisgard in 1975 (Channabasavanna et. al., 1976) as a number one enemy of rice in the command areas. The pest is distributed in all the command areas of the state. During eighties and 2002 and 2009, the severe outbreak of this pest was noticed in Bilaspur, Durg, Mahasamund, Dhamtari command areas. Mixed populations of $\mathrm{BPH}$ and white backed planthopper was reported from cauvery command area(Gubbaiah et. al., 1987). Apart from these pests, swarming caterpillar (Spodoptera mauritia Boisdual), blue beetle(Leptispa pygmaea Baly), armyworm (Mythimna separate Walker) orange-headed 3 leafhopper [(Thaia subrufa (Motsch.)] and coorge hairy caterpillar, under rain fed low land ecosystem and sporadic incidence of hispa, horned caterpillar (Melanitis leda smene Cramer), green leafhopper (Nephotettix nigropictus Stal.) and white leafhopper (Cofana spectra Distant), thrips (Stenchaetothrips biformis Bagnall), paddy skipper [Pelopidas mathias (Fabricius)], caseworm (Parapoynx stagnalis=Nymphula depunctalis Guenee), Atractomorpha crenulata Fabricius, earhead bugs [(Leptocorisa acuta (Thunberg), L. oratoria)] and grasshopper (Oxya yezoensis) have been reported in different parts of the state.

\section{Objective of the Study}

- To study has helped to identify insect life cycle to check economic loss to farmer.

- To study help into choosing of insecticides in various stage of insect.

- To study has help to economic enhancements of crop and market value of product.

- To get economic production it is essential to combine all suitable techniques and methods of pest suppression in as compatible a manner as possible to maintain pest populations at levels below those causing economic injury.

\section{Material and Method}

\subsection{Study Area}

Irrigated rice fields are temporary wetland agro-ecosystems, managed with a variable degree of intensity. A survey was carried out in Sri Lanka to document the overall biodiversity associated with this unique agro-ecosystem, using a combination of sampling techniques to document different groups of fauna and flora. The total number of biota recorded and identified from the rice field ecosystem during the entire study period consisted of 494 species of invertebrates belonging to 10 phyla and 103 species of vertebrates, while the flora included 89 species of macrophytes, 39 genera of microphytes and 3 species of macro fungi of the total species documented, 15 species of invertebrates and one weed species are new records to Chhattisgarh. Arthropods were the dominant group of invertebrates (405 species), of which 55 species were rice pest insects, and 200 species were natural enemies of pest insects.

The fauna and flora recorded from the rice field were observed to follow a uniform pattern of seasonal colonization and succession during successive rice cultivation cycles. The biodiversity of the irrigated rice agro- ecosystem interests both agro-ecologists and conservation biologists. Therefore, the integrated efforts of these two groups can result in the formulation of strategies based on biodiversity as an organizing principal in the sustainable management of the rice field agro-ecosystem.

Fingeshwar is a village panchayat located in the Raipur district of Chhattisgarh state,India. The latitude 20.9680118 and longitude 82.040062 are the geocoordinate of the Fingeshwar. The other nearest state capital from Fingeshwar is Bhubaneswar and its distance is $403.0 \mathrm{KM}$. The other surrouning state capitals are Bhubaneswar 403.0 KM., Ranchi 430.7 KM., Bhopal 540.6 KM., Hyderabad 545.1 KM.

\subsection{Fingeshwar Map}

The following Fingeshwar map is from google. Fingeshwar map consist of nearest villages and more information based on the zooming. You can enlarge or minimize the map zooming level based on your requirement. Dear Fingeshwar people we have started this wikiedit.org to publish all village details around the world. You are welcome to provide more information about Fingeshwar. It can be under the following category.

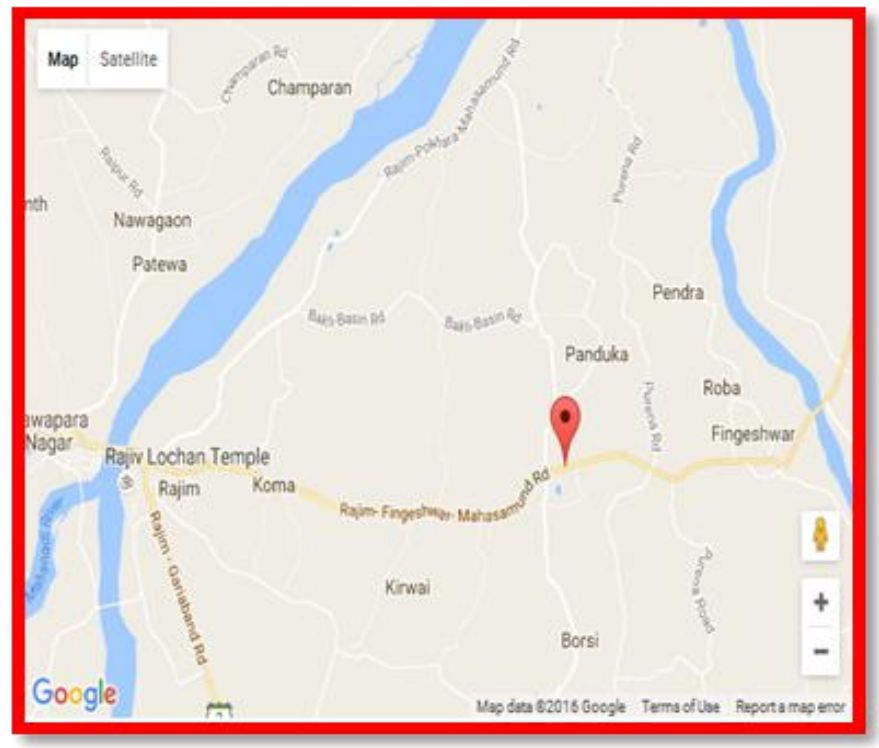

Figure 2: Map of Fingeshwar Region

\subsection{Minor Rice Insects}

Rice is sometimes damaged by insects that originate in and prefer crops other than rice. Examples of these crossover pests include armyworms and aphids. Occasionally rice stalk borers, billbugs, rice seed midges, short-horned grasshoppers, fall armyworms, chinch bugs or rice root aphids will become numerous and may cause noticeable damage to rice. A brief description of these pests and possible cultural and chemical control measures are provided in the following section.

\subsection{Scouting and Management}




\subsubsection{Sampling for Rice Water Weevil Larvae}

The oldest scouting method in rice, larval counts, is not often used today because insecticides that were used in the past are no longer available and foliar-applied insecticides currently used are targeting the adult stage, not the larval stage. However, this method may be used to decide on nonchemical management decisions, such as pulling the flood and draining the field, which may reduce larval injury or aid in plant recovery. Other scouting methods have become more useful in scouting for adults, which are the target for current foliar insecticides. Scouting for larvae is the same in drill seeded and water-seeded rice and should be conducted 2 to 3 weeks after permanent flooding. Rice plants and soil that surrounds the root system can be used to determine the larval infestation. The size of the soil/plant sample should be 4 inches in diameter and 3 to 4 inches deep in a silt loam soil and 2 to 3 inches deep in a heavy clay soil. Place the soil/plant sample in a bucket that has a 40-mesh screen bottom. Wash the soil from the plants by vigorously swirling the plants in the water to dislodge larvae from the roots. Move the sample vigorously up and down in the water several times to help wash away the soil. Most larvae will float to the water surface and can be removed from the bucket and counted. Continue to repeat the soil removal motions and larval counts until no additional larvae float to the surface or are visible in debris inside the bucket. Additional samples may be needed in large fields. The number and size of larvae can be used to predict how much 35 damage has and/or will occur in dry-seeded rice, if the samples are taken during peak densities. Recent studies in Texas indicate a yield loss of 1 percent for every larva per core.

\subsection{Selection Site}

The study was conducted in the months of February to July for cropping season in this year 2016 in Fingeshwar region. Research have choose of three villages: Binauri, Lachkera and Beltukri of 50 Farmars in Fingeshwar area. During the survey, face-to-face interviews of farmers chosen at random method, were conducted in co-operation with Agricultural Extension and Plant Protection. All interviews were conducted in the afternoon when farmers were mostly available at their farm houses or in their rice fields. Each interview took about 30 to $60 \mathrm{~min}$. The theme of interviews was to obtain a clear picture of the farmers' farming practices in their rice crop. The questions were asked in local (Chhattisgarhi) language in simple words and the answers were then translated into English and finally the questionnaire was completed accordingly.

\section{Ravi Crop:}

Total Hectare field -8762

Total Paddy Production - 473718 Quintal

The study was conducted in the months of June to November for cropping season in this year 2016 in Fingeshwer region.

\section{Kharib Crop:}

Total Hectare field - 30377

Total Paddy Production - 1670735 Quintal
There are major effect of insect in paddy crop and effect of major economic problem of Farmer.

\subsection{Sample Collection}

\subsubsection{Insect Collection}

Rice fields of the study area were observed rice in insect diversity. The predominance of non-heterocystous rice insect verious species was observed at all the rice fields of three villages : Binauri, Lachkera and Beltukri in Fingashwar region. Rice fields in the same growing season, passes through different physical states i.e., aquatic, semi aquatic and dry or terrestrial phase. Besides this all insect capture methods are biased towards catching insects of certain size, mass or flight behavior. It is therefore, a single insect collecting technique November is biased as some insect species September-November over represented while other might be underestimated or even missing. Therefore, multiple sampling techniques were adopted by applying same sampling methods in all sites and a large number of specimens were collected by using various sampling methods i.e., sweep net, light traps, pit fall traps and aquatic nets of standard sizes.

\subsubsection{Insect Preservation and Identification}

The collected specimens were sorted, pinned, labeled and mounted in collection boxes and minute specimens were preserved in glass vials in 70\% ethyl alcohol in the "Insect Biodiversity and Biosystemics Lab" (IBBL) Department of Agri. Entomology, University of Agriculture. The collected specimens were manually sorted into recognizable taxonomic units, counted and identified under stereo-zoom microscope with the help of available taxonomic literature and reference museum collection (in insect Biodiversity and Biosystematics Laboratory and insect Museum, Department of Agriculture Entomology, University of Agriculture possibly up to species level or otherwise to morph species within known genera or families and those, not identified even to family level, or their identification was not possible because of their damaged parts were left out of the analysis of diversity (Wickramasinghe et. al., 2004). The insects were then also sorted according to their tropic groups to make guild structure on various crop growth stages. Field observations and literature review were used to assign each species to one of five tropic categories used. Voucher specimens were deposited in a reference collection housed with IBB1, University of Agriculture.

The incidence of rice leaf folder, Cnapholocris medinalis Guenee was recorded through the damaged leaves and total number of leaves from 10 randomly selected hills at four spots (m2) in both midland normal transplanted (MNT) and SRI rice ecosystem (MSR) modified according to. Correlation analysis was carried out between field incidence of stem borer and weather parameters during Kharif season 2015-16. Regression analysis was worked out as per method given by researcher. The percentage of leaf damage was calculated as follows:

Percent incidence $=($ No. of damaged levels/Total no. of leaves)*100 


\section{International Journal of Science and Research (IJSR) \\ ISSN (Online): 2319-7064}

Index Copernicus Value (2015): 78.96 Impact Factor (2015): 6.391

\subsubsection{Rice Crop Pests}

The rice crop is ravaged by a much large number of insect pests than any other cereal crops in Fingeshwar rice filed. As many as 90 insect species have been recorded to feed on different parts of the plant from seedling stage till harvest of the crop in chhattisgarh. About one-fifth of them are considered to be important or major pests causing enormous loses of rice crop. It has been estimated that rice crop alone suffers damage due to pests and diseases to the extent of Rs. 100 crores annually. Out of which the loss caused by rice stem borer alone is about Rs. 10 crores. This crop, therefore, requires more attention on 'Protection Technology' in order to obtain maximum production per unit Fingeshwar area. The following various insect pests have been observed attacking in Fingeshwar rice fields:-

Table 1: Stage of rice and name of insect species

\begin{tabular}{|c|c|c|c|}
\hline $\begin{array}{c}\text { S. } \\
\text { No }\end{array}$ & $\begin{array}{c}\text { Stages of Rice } \\
\text { Crop }\end{array}$ & \multicolumn{2}{|c|}{ Name of Insect } \\
\cline { 3 - 4 } & Seedling Stage & $\begin{array}{c}\text { Common Name } \\
\text { Small rice } \\
\text { grashopper }\end{array}$ & Aoological Name \\
\hline 2 & Leaf eating & Kharif grasshopper & $\begin{array}{c}\text { Hieroglyphus } \\
\text { nigrorepletus }\end{array}$ \\
\hline 3 & $\begin{array}{c}\text { Leaf eating and } \\
\text { rolling }\end{array}$ & Rice caseworm & $\begin{array}{c}\text { Nymphula depunctalis } \\
\text { Guen. }\end{array}$ \\
\hline 4 & $\begin{array}{c}\text { Leaf and stem } \\
\text { sucking }\end{array}$ & Green leaf hopper & $\begin{array}{c}\text { Nephotellix vurescens } \\
\text { Dist. }\end{array}$ \\
\hline 5 & $\begin{array}{c}\text { Stem boring } \\
\text { Yellow stem borer }\end{array}$ & $\begin{array}{c}\text { Scirpophaga } \\
\text { interculas Wlk }\end{array}$ \\
\hline 6 & $\begin{array}{c}\text { Flower eating } \\
\text { Oxycetonia } \\
\text { albopunctata Fb }\end{array}$ \\
\hline 7 & Grain sucking & Rice gundhy bug & $\begin{array}{c}\text { Leptocorisa varicornis } \\
\text { Fabr. }\end{array}$ \\
\hline 8 & Root damaging & White grub & $\begin{array}{c}\text { Lachnosterna } \\
\text { longipennis Blanchard }\end{array}$ \\
\hline 9 & Gall making & Rice gall fly & Orseolia aryzae WM \\
\hline
\end{tabular}

\subsection{Statistical Analysis}

The researcher have used the percentage formulation for data collection in the work.

\subsection{Control of the Insecticide and Pesticide Methods}

This section provides an introductory discussion of the various types of pest control strategies known and applied in Tanzania. This includes a brief review of techniques for biological control, cultural control, chemical control, quarantine and physical or mechanical control, chemical control and botanical control are presented.

\subsubsection{Chemical Control}

Chemical control More than three key pests with different mode of feeding attack the rice crop. Stem borer remains inside the stem, leaf folder with in a leaf fold and BPH at the base of the plant. This has made rice pest management highly complicated. Insecticides play a pivotal role in rice pest management as evidenced in the late sixties and early seventies.

\section{Analysis and Data Interpretation}

Analysis is therefore the process in which the relationship or differences supporting or conflicting with the original or new hypothesis should be subjected to statistical tests of significance to determine with what validity data can be said to indicate any conclusions. It involves a number of operations which are performed with the purpose of summarizing the collected data and organizing these in a manner that they answer the research questions.

Interpretation of the data aims at drawing of inferences from the collected facts after the analytic study of the problem. It is extremely useful and important part of the study because it makes all possible use of the collected facts. Statistical facts by themselves have no utility. It is the interpretation that makes it possible for us to. Utilize collected data in various fields of activity. Interpretation is by no means a mechanical process. It requires a critical, examination of the results of one's analysis in the light of the limitations of the data gathering. As such it is a vital step and a part of the research process.

\subsection{Analysis According to Questionnaire}

Socio-economic conditions of the farmers: Socioeconomic conditions included educational level, age and land holding of the 50 farmers. They have a strong influence on farmers' perceptions of pests, pesticides and other management practices (Rola and Pingali, 1993). Actually, these conditions are the driving forces leading to the general trends in land use, biodiversity and environ-mental management. Some important aspects of socio-economic conditions of farmers of the Fingeshwar Regions are discussed below.

\subsection{Farmers' Attitude and Practices of Pest Management}

In this section, average number of application of various pesticides, change in pesticides usage, increase in usage of pesticides, and preference for aerial spray against rice pest insects are reported.

\section{Average number of application of various pesticides}

The frequency of insecticides used by the farmers only once was $54.0 \%$, while $45.3 \%$ farmers used insecticides twice in single rice crop season. The number of farmers using herbicides once in rice was 88.0 and $6.7 \%$ farmers used herbicides either two times or used two types of herbicides at the same time by mixing them or one after the other. The frequency of fungicides used once was found to be $30.7 \%$, while $4.7 \%$ farmers used fungicides twice. On the other hand, $0.7,5.3$ and $64.7 \%$ of the farmers were those not using insecticides, herbicides and fungicides, respectively, in rice crop.

Table 2: Average number of applications of various pesticides in rice crop

\begin{tabular}{|c|c|c|c|c|}
\hline \multirow{2}{*}{$\begin{array}{c}\text { Name of } \\
\text { pesticide }\end{array}$} & \multicolumn{2}{|c|}{ Once } & \multicolumn{2}{c|}{ Two times } \\
\cline { 2 - 5 } & $\begin{array}{c}\text { Frequenc } \\
y\end{array}$ & $\%$ & $\begin{array}{c}\text { Frequenc } \\
y\end{array}$ & $\%$ \\
\hline Insecticides & 81 & $54 \%$ & 68 & $45.3 \%$ \\
\hline
\end{tabular}

Volume 6 Issue 1, January 2017 


\section{International Journal of Science and Research (IJSR)}

ISSN (Online): 2319-7064

Index Copernicus Value (2015): 78.96 | Impact Factor (2015): 6.391

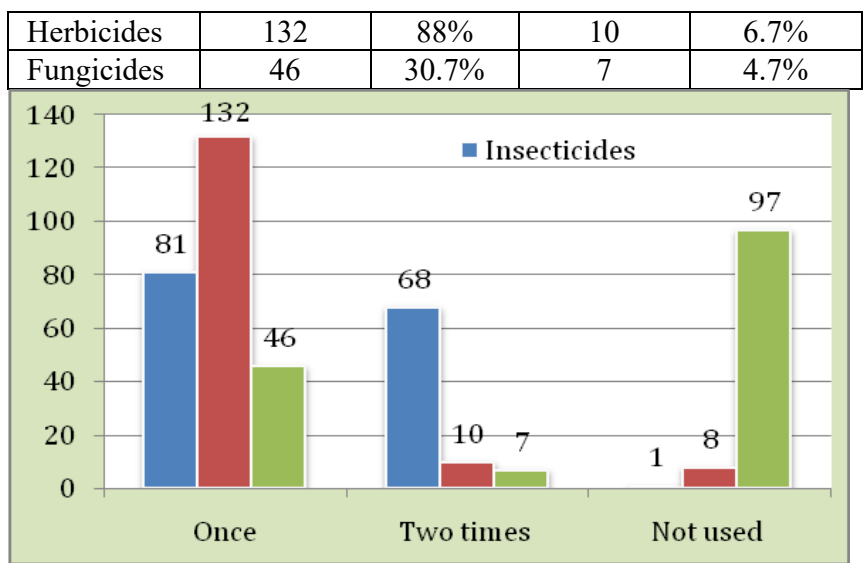

Graph 1: Average number of applications of various pesticides in rice crop

Table 3: Change in use of pesticides Change in use of pesticides

\begin{tabular}{|c|c|c|}
\hline \multicolumn{3}{|c|}{ Change in use of pesticides } \\
\hline Farmer's view & Frequency & Percentage \\
\hline Increased & 32 & $64 \%$ \\
\hline Decreased & 08 & $16 \%$ \\
\hline No change & 07 & $14 \%$ \\
\hline No response & 3 & $6 \%$ \\
\hline
\end{tabular}

Table 4: Increased use of pesticides

\begin{tabular}{|c|c|c|}
\hline \multicolumn{3}{|c|}{ Increased use of pesticides } \\
\hline Name of pesticide & Frequency & Percentage \\
\hline Insecticides & 30 & $60 \%$ \\
\hline Herbicides & 10 & $20 \%$ \\
\hline Fungicides & 8 & $16 \%$ \\
\hline No response & 2 & $04 \%$ \\
\hline
\end{tabular}

\section{Change in use of pesticides} Frequency

- Increased

No change

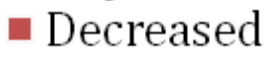

- No response
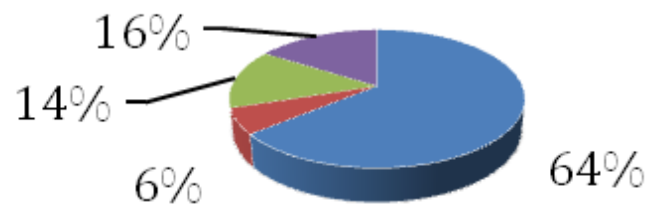

Graph 2: Change in pesticides' usage during the last five years

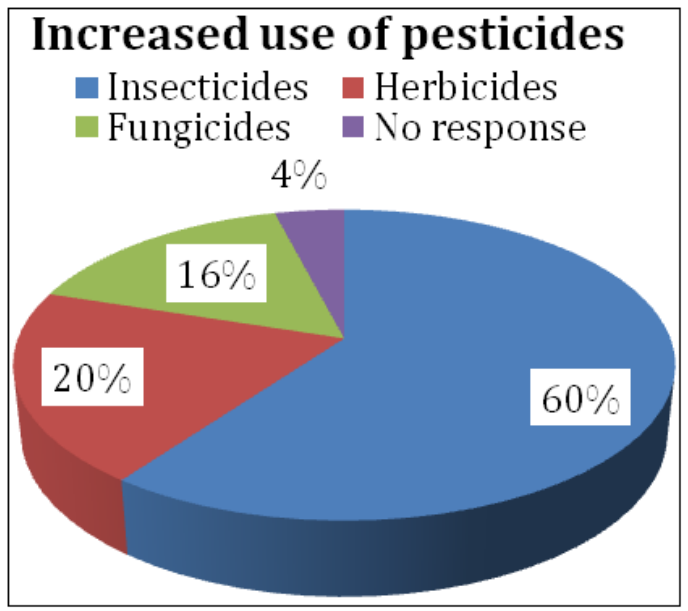

Graph 3: Change in pesticides' usage during the last five years

Table 4: Farmers' preference for aerial spray against rice crop pest insects

\begin{tabular}{|l|c|c|}
\hline \multicolumn{1}{|c|}{ Farmers' response } & Frequency & Percentage \\
\hline Yes & 38 & $76 \%$ \\
\hline No & 04 & $08 \%$ \\
\hline No response & 08 & $16 \%$ \\
\hline
\end{tabular}

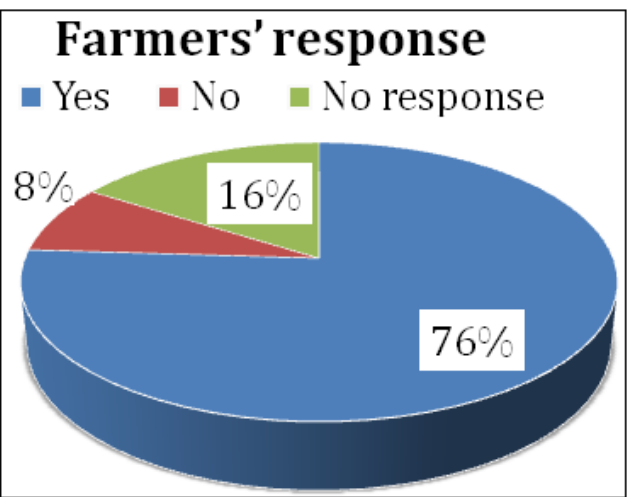

Graph 4: Farmers' preference for aerial spray against rice crop pest insects

\subsection{Improper/imbalance use of fertilizers}

Among 50 farmers, the farmers not using urea, diammonium phosphate (DAP) and potash were 3.3, 16.7 and $73.3 \%$, respectively. The farmers using urea, DAP and potash up to $1 \mathrm{bag} /$ acre were $36.7,68.0$ and $26.7 \%$, respectively. It is also clear that a big segment of the farmers (57.3\%) used urea fertilizers@ up to 2 bags/acre. The farmers using DAP @2 bags/acre were $15.3 \%$. There was a small portion $(1.7 \%)$ of the farmers using Urea@more than 2 bags/acre. However, none of the farmers interviewed was using potash @ 2 or more than two bags per acre. It is evident that among the other reasons of high attack of diseases and insects, the imbalance use of fertilizers is of utmost important, especially the excessive use of nitrogenous fertilizers, that is, urea and DAP.

The high nitrogen application, to get higher yields for more profits and due to more food demands, has increased pest intensities, which demands more pesticides (Heong et al., 1995) which ultimately deteriorates ecosystems. It is estimated that about $60 \%$ of fertilizers applied are left behind as residues and pollute the underground water, rivers, lakes and modify soil microbial ecology, by affecting the diversity of soil microflora and fauna (Heong and Escalada, 2005).

Table 5: Fertilizers used by rice farmers

\begin{tabular}{|c|c|c|c|c|}
\hline \multirow{2}{*}{$\begin{array}{c}\text { Amount of fertilizer used } \\
\text { @ kg/acre }\end{array}$} & \multicolumn{2}{|c|}{ Urea } & \multicolumn{2}{c|}{ DAP } \\
\cline { 2 - 5 } & Frequency & $\%$ & Frequency & $\%$ \\
\hline No use & 2 & 3.3 & 25 & 16.7 \\
\hline $0-50$ (1 bag) & 21 & 36.7 & 102 & 68 \\
\hline $51-100$ (up to 2 bags) & 86 & 57.3 & 23 & 15.3 \\
\hline $101-150$ (>than 2 bags) & 4 & 1.7 & 0 & 0 \\
\hline
\end{tabular}

Table 6: Fertilizers used by rice farmers

\begin{tabular}{|c|c|c|}
\hline \multirow{2}{*}{$\begin{array}{c}\text { Amount of fertilizer used @ } \\
\text { kg/acre }\end{array}$} & \multicolumn{2}{|c|}{ Potash } \\
\cline { 2 - 3 } & Frequency & $\%$ \\
\hline No use & 110 & 110 \\
\hline $0-50(1 \mathrm{bag})$ & 40 & 40 \\
\hline
\end{tabular}




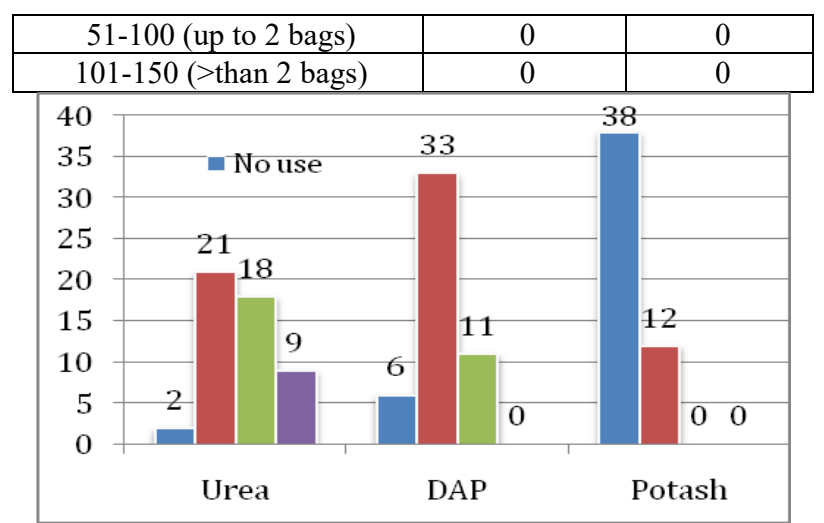

Graph 5: Fertilizers used by rice farmers

Table 7: Practices of insecticides application

\begin{tabular}{|l|c|c|}
\hline \multicolumn{1}{|c|}{ Farmers' views } & $\begin{array}{c}\text { Frequenc } \\
\text { y }\end{array}$ & $\begin{array}{c}\text { Percentag } \\
\text { e }\end{array}$ \\
\hline Not use insecticides & 1 & 0.7 \\
\hline After looking pest & 70 & 46.7 \\
\hline After looking damage consulting Agriculture & 20 & 13.3 \\
\hline $\begin{array}{l}\text { After } \\
\text { Department }\end{array}$ & 14 & 9.3 \\
\hline Following the neighbour & 40 & 26.7 \\
\hline Routine wise & 55 & 36.7 \\
\hline At ETL & 1 & 0.7 \\
\hline
\end{tabular}

\section{Conclusion}

Most of the farmers were of low educational level, belonged to middle or old age groups and had small land holdings of less than five hectares. The Agriculture Extension Department should take into account the socio-economic conditions of the farmers for any extension-training program and to target only a specific category of people in extension work to obtain desired results.

Even though insecticides are problematic for the health of farmers, an increasing trend in their use was found. The farmers must be internalized of pesticide use and assured that a wide gap exists between visible and actual damage. Farmers' awareness of the pesticides' hazards to the environment, animal and human health should be included in the local extension activities.

Most of the farmers did not follow the recommendations by the Department of Agriculture or by experts in the case of agrochemical usages. The increasing use of pesticides, improper uses of fertilizers, rice straw burning and coverage of large area by a single variety were of major importance. Hence, more conducive and concrete policies, regulations and enforcement systems are required in this regard, especially for pesticides and rice straw burning. Lastly, it is suggested that there must be a positive change in attitude and philosophy among decision-makers, scientists and others stakeholder to acknowledge alternatives. So that, while formulating policies and extension training programs regarding agriculture, hazards of pesticides, increasing average age of farmers and encouraging young people to choose farming as a profession, promoting a sense of pride in farmers, making farming both environmentally and economically sustain-able, food security and conservation of biodiversity should be addressed. This research will, however, open the doors to analyze the existing farming practices in deep and the ultimate results will be helpful in changing methods and materials in extension and farmer training and in modifying those management practices and approaches of farmers which are harming the insect biodiversity.

\section{References}

[1] Apha, $14^{\text {th }}$ ed. Standard methods for the examination of water and waste water, Washington, D.C. (1998)journal style)

[2] Bharos, A. M. K. and Kanoje, R. S., Wetlands of Kotmi Sonar, an abode of marsh Crocodile, Proceedings of Taal, The 12th world lake conference, 1796-1997, (2007).

[3] Ahmad I, Iram S (2006). Issues and analysis. Rice-wheat system sustainability concerns and soil born Pathogens. Available http://www.pakissan.com/english/issues/index/shtml. Accessed on: 05.09.2006

[4] Akhtar W, Sengupta D, Chowdhury A (2009). Impact of pesticides use in agriculture: their benefits and hazards. Interdisc Toxicol. 2(1):1-12.

[5] Anonymous (2001a). Biodiverse Systems are More Productive. Available at: http://www.isis.org.uk/BiodiverseisProductive.php?printing=yes. Accessed on: 16.05.2012.

[6] Anonymous (2001b). Country status report Nepal, a national case study on the integration of biodiversity into EIA, for the IAIA backed action programme on biological diversity and impact assessment under the UNEP/UNDP/GEF biodiversity planning support programme, Kathmandu, Nepal.

[7] Anonymous (2002). Young people and agriculture. Available http://www.anancy.net/documents/file_en/RRRP_021 Eng Pack.pdf. Accessed on 18.10.2010.

[8] Anonymous (2003). Export of rice from Chhattisgarh. Available at: http://goliath.ecnext.com/coms2/gi_0199316684/Export-of-rice-from-Chhattisgarh.html\#readmore. Accessed on: 07.03.2009.

[9] Balasubramaniam, A. and Ooi, P. A. C. 1977 Status of rice stem-borers following double cropping in Krian, Malaysia. Malaysian Agricultural Journal 51: 54-61.

[10] Bandong JP, Canapi BL, dela Cruz CG, Litsinger JA (2002). Insecticide decision protocols: a case study of untrained Filipino rice farmers. Crop Prot. 21:803-816

[11] Bandong JP, Canapi BL, dela Cruz CG, Litsinger JA (2002). Insecticide decision protocols: a case study of untrained Filipino rice farmers. Crop Prot. 21:803-816

[12] Berg H (2001). Pesticide use in rice and rice-fish farms in Mekong Delta, Vietnam. Crop Prot. 20:897-905.

[13] Dawe D (2008). The second Green Revolution-trends and implications

[14] Fernandez R (2005). Global rice production continues to decline. Available

at: http:www.asiarice.org/asiarice/demosite/sections/whatsnew Accessed on: 02.10.2006

[15] Heong KL, Escalada MM (2005). Scaling up communication of scientific information to rural communities. J. Sci. Commun. 4(3):1-3.

[16] Heong KL, Escalada MM, Huan NH, Ky Ba VH, Quynh PV, Thiet LV, Chien HV (2008). Entertainment-education and rice pest management: A radio soap opera in Vietnam. Crop Prot. 27:1392-1397 